\title{
CONTRIBUTION TO THE KNOWLEDGE ABOUT THE PRESENCE AND ROLE OF ENTEROBACTER GERGOVIAE IN SENSORY CHARACTERISTICS OF DAIRY PRODUCTS
}

\author{
Katarina G. Mladenović ${ }^{1 *}$, Mirjana Ž. Grujović1 ${ }^{1}$ Ljiljana R. Čomić ${ }^{1}$ \\ ${ }^{1}$ University of Kragujevac, Faculty of Science, Department of \\ Biology and Ecology, Kragujevac, Republic of Serbia
}

\begin{abstract}
Enterobacter gergoviae KGPMF 20 was found in traditionally made cheese from Sokobanja (South-eastern Serbia). In this paper, the characteristics of the species were evaluated by investigation of adhesion to different solvents and co-aggregation ability with other species. Moreover, its enzymatic activity was evaluated by using spectrophotometric method, with the intention to detect the role of the isolate in the sensory characteristic of cheese. The results of enzymatic activity indicated that E. gergoviae KGPMF 20 has low, almost no enzymatic activity. It could be concluded that this isolate did not affect the sensory characteristic of cheese.
\end{abstract}

Key words: Enterobacter gergoviae KGPMF 20, cheese originating from Serbia, enzymatic activity

\footnotetext{
${ }^{1}$ Corresponding author: katarina.mladenovic@pmf.kg.ac.rs
} 


\title{
DOPRINOS SAZNANJIMA O PRISUSTVU I ULOZI ENTEROBACTER GERGOVIAE U ORGANOLEPTIČKIM KARAKTERISTIKAMA MLEČNIH PROIZVODA
}

\author{
Katarina G. Mladenović1 ${ }^{*}$, Mirjana Ž. Grujović ${ }^{1}$, Ljiljana R. Čomić ${ }^{1}$ \\ ${ }^{1}$ Univerzitet u Kragujevcu, Prirodno-matematički fakultet, Odeljenje \\ za biologiju i ekologiju, Kragujevac, Republika Srbija
}

\section{Kratak sadržaj}

Enterobacter gergoviae KGPMF 20 pronađen je u tradicionalno proizvedenom siru iz Sokobanje (jugoistočna Srbija). U ovom radu, procenjene su karakteristike vrste ispitivanjem sposobnosti adhezije sa različitim rastvaračima i sposobnosti koagregacije sa drugom vrstom. Enzimska aktivnost vrste je procenjena spektrofotometrijskom metodom, sa namerom da se utvrdi uticaj vrste u organoleptičkim karakteristikama sira. Rezultati enzimske aktivnosti pokazali su da E. gergoviae KGPMF 20 pokazuje slabu enzimsku aktivnost. Na osnovu rezultata, može se zaključiti da vrsta nema uticaj na organoleptičke karakteristike sira.

Ključne reči: Enterobacter gergoviae KGPMF 20, sir iz Srbije, enzimatska aktivnost

\section{INTRODUCTION}

Cheese from Sokobanja (Southeastern Serbia) is made from unpasteurized cow milk. Since potentially pathogenic bacteria are not eliminated by high temperatures during the pasteurization process, they may be found in cheese. Enterobacter gergoviae is a member of the Enterobacteriaceae family and it was isolated from the cheese originating from Sokobanja (Mladenovic et al., 2018). Enterobacter gergoviae can be isolated from fresh cow's milk (Wahyuni and Budiarso, 2009), and from traditional cheese as well (Ethiopian cottage cheese) (Melkamsew et al., 2012).

Based on its occurrence in dairy products, the objective of this study was to investigate E. gergoviae KGPMG 20 isolated from traditionally produced cheese from Sokobanja (Serbia). The ability of adhesion in the presence of solvents, co-aggregation ability with Enterococcus faecalis KGPMF 49, and the potential to produce extracellular enzymes were examined. 


\section{MATERIALS AND METHODS}

The tested cheese was produced in a traditional way, in countryside households around Sokobanja (Southeastern Serbia). The methods of production, sampling, and analyses of chemical characteristics of cheese were described in Mladenović et al. (2018). E. gergoviae species KGPMG 20 was found in cheese. Biochemical characteristics and identification of the species were described in Mladenović et al. (2018).

\section{The adhesion to solvents}

The adhesion to solvents of E. gergoviae KGPMG 20 was measured in accordance with the method described in Rosenberg (1980), with some modifications (Bellon-Fontaine et al., 1996; Kos et al., 2003). After incubating the bacteria in TSB for $24 \mathrm{~h}$, the bacteria were centrifuged at $5000 \mathrm{rpm}$ for 15 minutes, and then washed twice and suspended in $0.1 \mathrm{M} \mathrm{KNO}_{3}(\mathrm{pH} \mathrm{6.2)}$ to

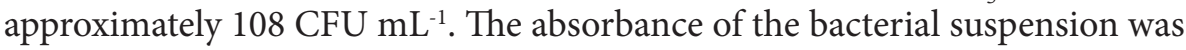
measured at $600 \mathrm{~nm}\left(\mathrm{~A}_{0}\right) .1 \mathrm{~mL}$ of solvent was added to $3 \mathrm{~mL}$ of bacterial suspension. After 10 minutes of incubation at room temperature, the two-phase system was mixed using a vortex for 2 minutes. The aqueous phase was removed after 20 minutes of incubation at room temperature and its absorbance was measured at $600 \mathrm{~nm}\left(\mathrm{~A}_{1}\right)$. The percentage of bacterial adhesion in the presence of solvent was calculated as follows:

$$
\text { Adhesion } \%=\left(1-\mathrm{A}_{1} / \mathrm{A}_{0}\right) \times 100
$$

Three different solvents were tested in this study: xylene (Sineks, Belgrade, Serbia), which is a polar solvent; chloroform (Alkaloid, Skoplje, Macedonia), a monopolar and acidic solvent, and ethyl acetate (Zorka, Sabac, Serbia), a monopolar and basic solvent. Only bacterial adhesion to xylene demonstrated cell surface hydrophobicity or hydrophilicity (Ocaña and Nader-Macías, 2002). According to Ocaña and Nader-Macías (2002), the percentage of hydrophobicity is expressed as 0 - 35\% - low hydrophobicity; 36 - 70\% - medium hydrophobicity; 71 - 100\% - high hydrophobicity.

\section{The co-aggregation ability}

The co-aggregation of E. gergoviae KGPMF 20 with Enterococcus faecalis KGPMF 49 isolated from the same Sokobanja cheese was examined. E. faecalis 
KGPMF 49 was isolated from the same cheese (Muruzović et al., 2018). The coaggregation was monitored by using a modified procedure described in Ocaña and Nader-Macías (2002). Overnight bacterial cultures were centrifuged at $5000 \mathrm{rpm}$ for 15 minutes, and then washed twice in PBS buffer (Alfa Aesar $\mathrm{GmbH} \& \mathrm{Co}$, Karlsruhe, Germany) followed by resuspension in $4 \mathrm{~mL}$ of the same buffer and the cell number was approximately $10^{8} \mathrm{CFU} \mathrm{mL} \mathrm{mL}^{-1} .2 \mathrm{~mL}$ of each suspension of both bacteria whose coaggregation was monitored was mixed well on a vortex. After mixing, $200 \mu \mathrm{L}$ from the surface of the suspension was transferred to a microtube containing $1800 \mu \mathrm{L}$ of PBS, and the absorbance values were read at $600 \mathrm{~nm}\left(\mathrm{~A}_{0}\right)$. The same procedure was repeated after 2 $h$ (At). The percentage of coaggregation of the species was calculated in the following way:

Coaggregation $\%=\left(A_{0}-A_{t}\right) / A_{0} \times 100$

\section{The preparation of fermentation liquid and detection of enzymatic activity}

In order to investigate the enzymatic activity, it is necessary to obtain fermentation liquids of the isolate. $100 \mu \mathrm{L}$ of overnight bacterial culture was separately inoculated in $10 \mathrm{~mL}$ of TSB (Torlak, Belgrade, Serbia) and MH (Torlak, Belgrade, Serbia). Inoculated broths were incubated for $24 \mathrm{~h}$ at $37^{\circ} \mathrm{C}$. After the incubation, the samples were centrifuged at $10.000 \mathrm{rpm} / 30 \mathrm{~min} / 4^{\circ} \mathrm{C}$. Then, the supernatant, which represented the fermentation liquid, was separated. Fermentation liquid was kept in the refrigerator at $4^{\circ} \mathrm{C}$ until the experiment was performed. Two broths were used as they had a different composition and there was a possibility that they could affect the enzymatic activity of bacteria.

After the preparation of fermentation liquid, the enzymatic activity was evaluated. The acid and alkaline invertase activity, the activity of alkaline phosphatase, $\alpha$-amylase activity, proteolytic activity and the total concentration of protein were all determined by the methods described in Jakovljević (2014).

\section{RESULTS AND DISCUSSION}

In this paper, the adhesion and co-aggregation ability, as well as the enzymatic activity of E. gergoviae KGPMF 20 were demonstrated for the first time. The isolate originated from Sokobanja cheese which was produced in the households around Sokobanja (southeastern Serbia), from fresh and unpasteurized cow's milk. According to the results from Mladenović et al. (2018), E. 
gergoviae KGPMF 20 is a gram-negative, oxidase negative and catalase-positive bacteria. It showed the fermentation ability of glucose and lactose with production of acid and gas, while the ability of $\mathrm{H}_{2} \mathrm{~S}$ production (hydrogen sulphide) form triple sugar was not detected. It formed a light pink colony on HiChrome coliform agar. The investigated isolate was sensitive to antibiotics (streptomycin, chloramphenicol and tetracycline).

The adhesion ability of E. gergoviae KGPMF 20 was detected in the presence of chloroform (13.85\%), and ethyl acetate (13.89\%). The species demonstrated no ability of adhesion in the presence of xylene.

Adequate hydrophobic/hydrophilic properties of microorganisms can contribute to beneficial processes such as degradation of hydrocarbons or biodegradable polyesters during milk fermentation (Obuekwe et al., 2009). Hydrophobic microorganisms may have the ability to form a biofilm to various abiotic and biotic surfaces (Krasowska and Karel, 2014). According to Tresse et al. (2006), cellular hydrophobicity is crucial for biofilm formation. Del Re et al. (2000) and Giaouris et al. (2009) indicated that bacteria with a hydrophobic surface have a higher binding affinity for epithelial cells and solid surfaces. Bacterial biofilm can lead to bacterial resistance to antibiotics and thus contributes to the pathogenicity of one species. Bacterial adhesion in the presence of xylene is an indicator of hydrophobicity or hydrophilicity of cell surface. The ability to adhere in the presence of two other solvents, chloroform and ethyl acetate is an indicator of the ability of bacterial cell as a donor of base or acid electron acceptors (Bellon-Fontaine et al., 1996). Based on the results, it can be concluded that E. gergoviae KGPMF 20 had low hydrophobicity. It showed no ability of adhesion to xylene, meaning that it had a low potential to attach and form biofilm in abiotic surfaces.

The co-aggregation of E. gergoviae KGPMF 20 and E. faecalis KGPMF 49 was investigated for the first time in this study. The percentage of co-aggregation between these bacteria was $14.2 \%$. Enterobacteria and enterococci are a member of the normal flora of the human gastrointestinal tract (Silva et al., 2012; Pugin et al., 2017) and of the dairy products made from unpasteurized cow's milk (Muruzović et al., 2018; Mladenović et al., 2018). Therefore, their interaction needs to be investigated and evaluated.

The enzymatic activity of E. gergoviae KGPMF 20 was investigated in two different broths and the results are shown in Table 1. The results indicated that small activity of amylase and alkaline phosphatase was observed, while the activity of acid and alkaline invertase was not detected (except for the very small activity of acid invertase in $\mathrm{MH}$ ). The protease activity was observed only in TSB. 
Table 1. The enzymatic activity of E. gergoviae KGPMF 20

\begin{tabular}{lcc}
\hline \multicolumn{2}{c}{ E. gergoviae KGPMF 20} \\
\hline \multicolumn{1}{c}{ Proteins and enzymes } & Type of media & Absorbance \\
\hline \multirow{2}{*}{ Protease $(\mathrm{IU} / \mathrm{mL})$} & TSB & 7.6 \\
\hline \multirow{2}{*}{ Total proteins $(\mathrm{mg} / \mathrm{mL})$} & MH & $/$ \\
\hline \multirow{2}{*}{ Acid invertase (IU/mL) } & TSB & 0.13 \\
& MH & 0.04 \\
\hline \multirow{2}{*}{ Alkaline invertase $(\mathrm{IU} / \mathrm{mL})$} & TSB & $/$ \\
& MH & 0.05 \\
\hline \multirow{2}{*}{ Amylase $(\mathrm{IU} / \mathrm{mL})$} & TSB & $/$ \\
& MH & $/$ \\
\hline \multirow{2}{*}{ Alkaline phosphatase $(\mathrm{IU} / \mathrm{mL})$} & TSB & 0.05 \\
& MH & $/$ \\
\hline
\end{tabular}

I - not detected

According to the results of the screening method, E. gergoviae KGPMF 20 does not have the proteolytic or lipolytic activity (Mladenović et al., 2018). According to a study by Kamaladevi et al. (2014), E. gergoviae isolated from the areas of Vaippar, Thoothukudi District and Tamil Nadu in India demonstrated the ability to produce lipase. In this paper, it was shown that E. gergoviae KGPMF 20 had a very low or no enzymatic activity, so it had no role in sensory properties of cheese.

In the Sokobanja cheese, the presence of the Enterobacter genus with only E. gergoviae KGPMF 20, was determined (Mladenović et al., 2018). Based on the available literature, it was found that the appearance and description of Enterobacter sp. is scarce compared to the description and presence of other members of the Enterobacteriaceae family (Tabla et al., 2016; Mladenović et al., 2018).

\section{CONCLUSION}

Based on the results from this study, E. gergoviae KGPMF 20 can interact with other species isolated from cheese. The species had a low hydrophobicity and showed no adhesion ability in the presence of xylene. It produces a very low concentration of extracellular enzymes, so it had no effect on the sensory 
characteristics of cheese. Previous results on this isolate showed its sensitivity to antibiotics. Therefore, the appearance of E. gergoviae in cheese is probably the result of a spontaneous transfer from an animal to fresh milk.

\section{ACKNOWLEDGMENTS}

This work was supported by the Serbian Ministry of Education, Science and Technological Development (No. 451-03-68/2020-14/200122).

\section{Authors' contributions}

KM made substantial contributions to basic idea, conception and design, acquisition of samples and data, analysis of the data and interpretation of results; MG was involved in drafting of the manuscript, revising it critically for important intellectual content, and LjČ gave the final approval of the manuscript to be published.

\section{Competing interests}

The authors declare that they have no competing interests.

\section{REFERENCES}

1. Bellon-Fontaine M.N., Rault J., van Oss C.J. 1996. Microbial adhesion to solvents: a novel method to determine the electron donor/electron-acceptor or Lewis acid-base properties of microbial cells. Colloids and Surfaces, 7, 1-2, 47-53. doi:10.1016/0927-7765(96)01272-6.

2. Del Re B., Sgorbati B., Miglioli M., Palenzona D. 2000. Adhesion, autoaggregation and hydrophobicity of 13 strains of Bifidobacterium longum. Letters in Applied Microbiology, 31, 438-442. doi:10.1046/j.13652672.2000.00845.x.

3. Giaouris E., Chapot-Chartier M.P., Briandet R. 2009. Surface physicochemical analysis of natural Lactococcus lactis strains reveals the existence of hydrophobic and low charged strains with altered adhesive properties. International Journal of Food Microbiology, 131, 1, 2-9. doi:10.1016/j.ijfoodmicro.2008.09.006.

4. Jakovljević D.V. 2014. Biochemical characteristics of selected fungal species as a function of detergent biodegradation. Doctoral dissertation, Faculty of Science, Kragujevac, Serbia (in Serbian). 
5. Kamaladevi B., Prabhavathi P., Sankareswaran M., Anbalagan S., Radhakrishnan N., Prabhu D. 2014. Screening and medium optimization of lipase producing bacteria from saltpan. Research Journal of Chemical and Environmental Sciences, 2, 72-77.

6. Kos B., Šušković J., Vuković S., Simpraga M., Frece J., Matošić S. 2003. Adhesion and aggregation ability of probiotic strain Lactobacillus acidophilus M92. Journal of Applied Microbiology, 94, 981-987. doi:10.1046/ j.1365-2672.2003.01915.x.

7. Krasowska A. and Karel S. 2014. How microorganisms use hydrophobicity and what does this mean for human needs? Frontiers in Cellular and Infection Microbiology 4, Article 112. doi: 10.3389/fcimb.2014.00112.

8. Melkamsew A.T., Pal M., Beda H.A. 2012. Bacteriological study on coliform organisms from Ethiopian traditional cheese west show zone. African Journal of Microbiology Research, 3, 3, 188-191. doi:10.5829/idosi. ijmr.2012.3.3.64213.

9. Mladenović K., Muruzović M., Žugić Petrović T., Stefanović O. Čomić Lj. 2018. Isolation and identification of Enterobacteriaceae from traditional Serbian cheese and their physiological characteristics. Journal of Food Safety, 38, 1, Article ID e12387. doi:10.1111/jfs.12387.

10. Muruzović M., Mladenović K., Žugić Petrović T., Čomić Lj. 2018. Characterization of lactic acid bacteria isolated from traditionally made Serbian cheese and evaluation of their antagonistic potential against Enterobacteriaceae. Journal of Food Processing and Preservation, 42, 4, Article ID e13577. doi:10.1111/jfpp.13577.

11. Obuekwe C., Al-Jadi Z.K., Al-Saleh E. 2009. Hydrocarbon degradation in relation to cell-surface hydrophobicity among bacterial hydrocarbon degraders from petroleum-contaminated Kuwait desert environment. International Biodeterioration and Biodegradation, 63, 273-279. doi:10.1016/j. ibiod.2008.10.004.

12. Ocaña V. and Nader-Macías M.E. 2002. Vaginal lactobacilli: self- and coaggregation ability. British Journal of Biomedical Science, 59, 4, 183-190. doi: 10.1080/09674845.2002.11783657.

13. Pugin B., Barcik W., Westermann P., Heider A., Wawrzyniak M., Hellings P. 2017. A wide diversity of bacteria from the human gut produces and degrades biogenic amines. Microbial Ecology in Health and Disease, 28, Article ID 1353881. doi:10.1080/16512235.2017.1353881.

14. Rosenberg M., Gutnick D., Rosenberg E. 1980. Adherence of bacteria to hydrocarbons: a simple method for measuring cell-surface hydrophobicity. FEMS Microbiology Letters, 9, 1, 29-33. doi:10.1111/j.1574-6968.1980. tb05599.x. 
15. Silva N., Igrejas G., Gonçalves A., Poeta P. 2012. Commensal gut bacteria: distribution of Enterococcus species and prevalence of Escherichia coli phylogenetic groups in animals and humans in Portugal. Annals of Microbiology, 62, 449-459. doi:10.1007/s13213-011-0308-4.

16. Tabla R., Gómez A., Simancas A., Rebollo J.E., Molina F., Roa I. 2016. Enterobacteriaceae species during manufacturing and ripening of semi-hard and soft raw ewe's milk cheese: Gas production capacity. Small Ruminant Research, 145, 123-129. doi:10.1016/j.smallrumres.2016.11.008.

17. Tresse O., Lebret V., Benezech T., Faille C. 2006. Comparative evaluation of adhesion, surface properties, and surface protein composition of Listeria monocytogenes strains after cultivation at constant $\mathrm{pH}$ of 5 and 7. Journal of Applied Microbiology, 101, 1, 53-62. doi:10.1111/j.13652672.2006.02968.x.

18. Wahyuni A.E.T.H. and Budiarso T.Y. 2009. Detection of Enterobacter sakazakii and another Enterobacter sp. from Dairy Cow's Milk in Boyolali and Sleman. Animal production, 74-77.

Submitted: 23.04.2020.

Accepted: 28.06.2020. 